\title{
The Holship ruling of the ECtHR and the protection of fundamental rights in Europe
}

\author{
Hans Petter Graver ${ }^{1}$
}

Accepted: 24 January 2022 / Published online: 1 February 2022

(c) The Author(s) 2022, corrected publication 2022

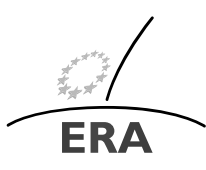

EUROPÄISCHE RECHTSAKADEMIE ACADEMY OF EUROPEAN LAW ACADEMIE DE DROIT EUROPEEN ACCADEMIA DI DIRITTO EUROPEO TRIER - TREVES - TREVIRI

\begin{abstract}
The status of trade union rights in the EU has been contentious since the CJEU sent shockwaves through the trade unions of Europe in December 2007 with its rulings in the cases of Viking and Laval. In its recent Holship ruling, the ECtHR has challenged these rulings. Contrary to the assertion of the CJEU in Laval that it is inherent in the very exercise of trade union rights and the right to take collective action that they will be prejudiced to a certain degree, the ECtHR stated that "the degree to which a collective action risks having economic consequences cannot (...) in and of itself be a decisive consideration in the analysis of proportionality under Article 11". This has potentially wide-reaching implications for the relationship between the human rights recognized in international human rights conventions and EU fundamental rights.
\end{abstract}

Keywords Fundamental rights · Posted workers · EU and Human Rights · EEA Agreement

The European Court of Human Rights (ECtHR) recently gave a ruling that may have implications for the balancing of fundamental rights in the EU. The case concerned the relationship between trade union rights and the right of establishment in Norway. Norway is not an EU Member State but is bound to the single market through the EEA Agreement which establishes "a dynamic and homogeneous European Economic Area, based on common rules and equal conditions of competition". 1

\footnotetext{
${ }^{1}$ EEA Agreement, recital 4.

H.P. Graver

h.p.graver@jus.uio.no

1 University of Oslo, Oslo, Norway
} 
The status of trade union rights in the EU has been contentious since the CJEU sent shockwaves through the trade unions of Europe in December 2007 with its rulings in the cases of Viking and Laval. ${ }^{2}$ In the Viking judgment, the CJEU denied that it is "inherent in the very exercise of trade union rights and the right to take collective action that those fundamental freedoms [...] will be prejudiced to a certain degree" (paragraph 52). In Laval it stated that "the freedom to provide services is one of the fundamental principles of the Community" and that "a restriction on that freedom is warranted only if it pursues a legitimate objective compatible with the Treaty and is justified by overriding reasons of public interest; if that is the case, it must be suitable for securing the attainment of the objective which it pursues and not go beyond what is necessary in order to attain it" (paragraph 101). Reiterating its rulings in Schmidberger and Omega, ${ }^{3}$ the Court emphasised that the right to collective action must be exercised within the framework of Union law.

With these decisions, the CJEU made the right of trade unions to take collective action subject to the requirements of the four freedoms. In its recent Holship ruling, the ECtHR has challenged this. ${ }^{4}$ The Strasbourg Court explicitly stated that from the perspective of Article 11 of the ECHR, the freedom of establishment is not a counterbalancing fundamental right to freedom of association but rather one element to be taken into consideration in the assessment of proportionality under Article 11 (2) ECHR. Contrary to the assertion of the CJEU in Laval that it is inherent in the very exercise of trade union rights and the right to take collective action that they will be prejudiced to a certain degree, the ECtHR stated that "the degree to which a collective action risks having economic consequences cannot (...) in and of itself be a decisive consideration in the analysis of proportionality under Article 11". 5 Since this case concerned the substantially equivalent rights under the EEA-agreement, this has potentially wide-reaching implications for the relationship between the human rights recognized in international human rights conventions and EU fundamental rights, seen from the perspective of Strasbourg. ${ }^{6}$

\section{Brief overview of the facts}

The background of the case was a conflict over dockworkers` rights to load and unload ships in the port of Drammen in Norway. According to a collective agreement, this work was the prerogative of dockworkers, organized in a local enterprise established by the union and the employer's association. The Danish Company Holship

\footnotetext{
${ }^{2}$ Case C-341/05 - Laval un Partneri EU:C:2007:809 and Case C-438/05 - International Transport Workers' Federation and Finnish Seamen's Union v Viking Line ABP and OÜ Viking Line Eesti EU:C:2007:772.

${ }^{3}$ Case C-112/00 Eugen Schmidberger, Internationale Transporte und Planzüge v Republik Österreich EU:C:2003:333 and Case C-36/02 Omega Spielhallen- und Automatenaufstellungs-GmbH v Oberbürgermeisterin der Bundesstadt Bonn EU:C:2004:614.

${ }^{4}$ Case of Norwegian Confederation of Trade Unions (LO) and Norwegian Transport Workers' Union (Ntf) v Norway (Application no. 45487/17) Judgment Strasbourg 10 June 2021.

${ }^{5}$ See para. 117.

${ }^{6}$ See Stylogiannis [14].
} 
challenged this right, with the result that the trade union threatened them with a boycott action.

The trade union lost the case in the Norwegian Supreme Court, which found the boycott illegal, as a disproportionate restriction of Holship 's right of establishment under the EEA-agreement. ${ }^{7}$ Under the agreement, the EU acquis regarding the four freedoms is part of Norwegian law. The case had been referred to the EFTA Court, which based its opinion on the Viking and Laval case-law of the CJEU. ${ }^{8}$ The EFTA Court, in reference to the CJEU in Viking, determined the agreement and the boycott to be a restriction on the right to establishment and set out detailed requirements for the assessment of the proportionality of this restriction. The Supreme Court followed up on this stating:

"The freedom of establishment [...] is a fundamental freedom in the EEA, and if the right to boycott is protected under Article 101, first paragraph, of the Constitution, these rights must be weighed against each other as part of a consideration of proportionality. [...] [J]ust as rights under the EEA Agreement can justify restriction of constitutional or conventional human rights, so can constitutional or conventional human rights justify restrictions of rights under the EEA Agreement" (paragraph 85).

This clearly puts the rights of the constitution, and thus human rights, on the same footing as the "fundamental freedoms" of the EEA agreement. The Supreme Court, in other words, mirrored the approach of the CJEU to conflicts between the market freedoms of EU law and the human rights recognized as fundamental rights under EU law.

In response, the trade union brought the case to the ECtHR. For matters under EU law and the jurisdiction of the CJEU, reference to the ECtHR is barred by the so-called Bosphorus doctrine. According to this doctrine, the ECtHR has declared that it will not hear cases regarding the implementation of EU law, the EU being "an organisation to which a Contracting State has transferred jurisdiction is considered to protect fundamental rights in a manner which can be considered at least "equivalent" to that for which the Convention provides". It was therefore presumed that the last word had been said about the relationship between fundamental freedoms of the EU and rights of the European Convention by the rulings of the CJEU.

\section{The state of EU law: a fundamental right, but also a restriction on free movement}

The EC and later the EU has always been primarily an economic community with emphasis on a single market and economic freedoms. It has not had as its aim to create a union of social states or welfare states. ${ }^{9}$ Even so, until its rulings in Viking and Laval in 2007, the CJEU never challenged labour rights head on, and no national

\footnotetext{
${ }^{7}$ The Supreme Court of Norway - Judgment - HR-2016-2554-P.

${ }^{8}$ EFTA Court - Judgment 2016-04-19 Case E-14/15.

${ }^{9}$ See Giubboni, Höpner and Scmidt [7, 9].
} 
regulation protecting the right of workers was set aside as an impermissible restriction on an economic freedom. ${ }^{10}$

The Posting Workers Directive ${ }^{11}$ established that an employment contract is to be governed by the law of the country in which the employee habitually carries out his work in performance of the contract. On the other hand, this should not deprive a worker of the protection of certain mandatory rules in the country where he temporarily performs his work. The issue soon to arise was whether this set a limit to the extent that Member States could extend their legislation or collective agreements to persons temporarily employed within their territory. The two first cases on this issue were decided by the CJEU in the Viking Line case in the ruling on 11 December 2007 and in the Laval case on 18 December $2007 .{ }^{12}$

As have been observed, the decisions in these cases "transform[ed] a rather traditional domestic labour dispute between two private actors (management and unions) into a clash between two fundamental European norms: the fundamental freedom of establishment (now horizontally effective against unions) and the fundamental right to collective action (now available to unions)". ${ }^{13}$

The rulings of the Court spurred reactions in many Member States and within the trade unions. ${ }^{14}$ The right to strike has been characterised as undoubtedly "one of the most important social human rights in the modern world". ${ }^{15}$ Nominally, in Viking Line, the Court set the fundamental right to collective action and the fundamental freedoms of establishment and to provide services on equal footing. It was early observed, however, that the real effect of Laval and Viking Line was to subordinate labour rights under the economic freedoms of the EU treaty. General Advocate Trstenjak stated in an opinion in 2010:

"The approach adopted in Viking Line and Laval un Partneri, according to which Community fundamental social rights as such may not justify - having due regard to the principle of proportionality - a restriction on a fundamental freedom but that a written or unwritten ground of justification incorporated within that fundamental right must, in addition, always be found, sits uncomfortably alongside the principle of equal ranking for fundamental rights and fundamental freedoms. Such an analytical approach suggests, in fact, the existence of a hierarchical relationship between fundamental freedoms and fundamental rights in which fundamental rights are subordinated to fundamental freedoms and, consequently, may restrict fundamental freedoms only with the assistance of a written or unwritten ground of justification." 16

\footnotetext{
${ }^{10}$ See Rebhanh [16].

${ }^{11}$ Directive 96/71/EC of the European Parliament and of the Council of 16 December 1996 concerning the posting of workers in the framework of the provision of services, OJ L 18, 21.1.1997, p. 1-6.

${ }^{12}$ See Barnard [1].

${ }^{13}$ Lasser [11], p. 242.

${ }^{14}$ Responses to the rulings by the CJEU in these cases in the Member States and indifferent international bodies are presented by Malmberg [13].

${ }^{15}$ Swiatkowski [15], p. 391.

${ }^{16}$ Case C-271/08 European Commission v Federal Republic of Germany EU:C:2010:183 para. 183 and 184.
} 
This approach of the CJEU put trade union measures on the same footing as state regulatory measures and not on the footing of fundamental rights, or as expressed by Lasser: Unions "must now treat the exercise of their own fundamental rights as secondary to the firm's fundamental market freedoms". ${ }^{17}$ The hierarchy has later been confirmed and maintained by the Court. In Fondship it stated that "any restriction which, without objective justification, is liable to prohibit, impede or render less attractive the provision of those services must be declared incompatible with EU law. (... ) That case-law includes the judgment in Laval un Partneri (C-341/05, EU:C:2007:809) relating to the compatibility of industrial action with the freedom to provide services". 18

It has been argued that the inclusion of the Charter of Fundamental Rights into the Treaty of Lisbon could lead to a re-evaluation of the relationship between social rights and economic freedoms. ${ }^{19}$ Article 6 TEU as amended in the Lisbon treaty states that the "Union recognises the rights, freedoms and principles set out in the Charter of Fundamental Rights of the European Union of 7 December 2000, as adapted at Strasbourg, on 12 December 2007, which shall have the same legal value as the Treaties." Furthermore, the EU-Charter states in Article 52 (3) that "In so far as this Charter contains rights which correspond to rights guaranteed by the Convention for the Protection of Human Rights and Fundamental Freedoms, the meaning and scope of those rights shall be the same as those laid down by the said Convention." In addition to ensuring at least the same level of protection by the EU courts as under the ECHR, the provision also requires the CJEU to reinterpret the charter in the case that the ECtHR raises the level of protection of a right of the ECHR or decides to expand its scope of application. ${ }^{20}$

The revision of the Posted Workers Directive in 2018 has been a further step in the direction of a recalibration of the relationship between free movement rights and trade union rights. A test of this was undertaken in the challenges of this revision by the governments of Hungary and Poland before the CJEU. ${ }^{21}$ The answer given by the Court may be open to several interpretations, but it can still be claimed that the Court maintains it stance from its previous case-law, and that its position on the role of collective rights has not shifted. ${ }^{22}$

\section{The European Convention on Human Rights}

How then is the conflict of rights seen from the perspective of the European Convention on Human Rights? Several things were clear even before the Holship case.

\footnotetext{
${ }^{17}$ Lasser [11], p. 251.

${ }^{18}$ See Case C-83/13 Fonnship A/S v Svenska Transportarbetareförbundet and Facket för Service och Kommunikation (SEKO) and Svenska Transportarbetareförbundet v Fonnship A/S EU:C:2014:2053.

${ }^{19}$ See to this Evju [5], p. 322

${ }^{20}$ See Lenaerts [12], p. 98.

${ }^{21}$ Cases C-620/18, Hungary v Parliament and Council EU:C:2020:1001 and C-626/18, Republic of Poland v Parliament and Council EU:C:2020:1000.

${ }^{22}$ Lasek-Markey [10], page 18 of 25.
} 
The right to form trade unions to protect workers' interests is part of ECHR Article 11 which states that "everyone has the right to freedom of peaceful assembly and to freedom of association with others, including the right to form and to join trade unions for the protection of his interests". This has also been seen to encompass the right to collective action, with the right to strike as an "indispensable part" of the right to form trade unions. ${ }^{23}$ The right to collective bargaining through trade unions was reinforced by the ECtHR in several decisions dating from after the seminal decisions of the CJEU. ${ }^{24}$ In R.M.T $v U K$ the Court confirmed that the right to take industrial action is included in ECHR Article 11, and characterised the right to strike as "clearly protected by Article 11". ${ }^{25}$ It also characterised the right to engage in collective bargaining as "essential". ${ }^{26}$ It can thus be claimed that the right to take collective action is at the core of the freedom of association in Article 11.

The second paragraph of Article 11 gives the state the right to restrict these rights in so far that it is "prescribed by law and (is) necessary in a democratic society in the interests of national security or public safety, for the prevention of disorder or crime, for the protection of health or morals or for the protection of the rights and freedoms of others". To be compatible with paragraph 2 of Article 11, an interference by the government must therefore be shown to be "prescribed by law", to pursue a legitimate aim, and to be "necessary in a democratic society" to achieve those aims". ${ }^{27}$ As usual, the state is accorded a margin of appreciation in deciding upon what restrictions are necessary and proportional. To this the Court in R.M.T. v UK stated:

"If a legislative restriction strikes at the core of trade union activity, a lesser margin of appreciation is to be recognised to the national legislature and more is required to justify the proportionality of the resultant interference, in the general interest, with the exercise of trade union freedom. Conversely, if it is not the core but a secondary or accessory aspect of trade union activity that is affected, the margin is wider and the interference is, by its nature, more likely to be proportionate as far as its consequences for the exercise of trade union freedom are concerned." 28

A contentious, and important issue is whether the impact of an industrial action on the employer can be taken into account in the "protection of the rights and freedoms of others" according to Article 11 paragraph 2. The trade unions have argued that this would be illogical because "the very purpose of strike action is to have a strong impact on the employer's position, to induce the employer to meet the demands of labour". ${ }^{29}$ The Court did not take a decision on this, since it found that Parliament in prohibiting

\footnotetext{
${ }^{23}$ See Edström [4], pp. 64-65. Russia, no. 67336/01, 30 juli 2009.

${ }^{25}$ R.M.T. v. The United Kingdom, no.31045/10, 27 August 2012 Para. 84

${ }^{26}$ R.M.T. v. The United Kingdom, no.31045/10, 27 August 2012 Para. 85.

${ }^{27}$ R.M.T. v. The United Kingdom, no.31045/10, 27 August 2012 para. 78.

${ }^{28}$ R.M.T. v. The United Kingdom, no.31045/10, 27 August 2012 para. 87.

${ }^{29}$ R.M.T. v. The United Kingdom, no.31045/10, 27 August 2012 para. 80.
}

${ }^{24}$ Se Demir and Baykara v. Turkey [GC], no. 34503/97, 12 November 2008, Enerji Yapi-Yol Sen v. Turkey, no. 68959/01, 21 April 2009, Barraco v. France, no 31684/05, 5 mars 2009 och Danilenkov and Others v. 
secondary industrial action had pursued the legitimate aim of protecting the rights and freedoms of others, not limited to the employer side in an industrial dispute. The Court on the other hand explicitly distinguished the case from the UNISON case (UNISON v. the United Kingdom (dec.), no. 53574/99, ECHR 2002-I), where the impact on the employer had been taken into account, thus leaving the door open to reverse its finding in UNISON.

\section{ILO conventions and the European Social Charter}

The ECtHR did not before Holship directly address the jurisprudence of the CJEU or the state of EU law on the status of the right to take collective action within this framework. The approach in EU law has, however, been the topic both of the European Committee of Social Rights on the European Social Charter and of the ILO Expert Committee on the ILO conventions.

The ILO Expert Committee was the first to be given the opportunity to comment upon the development in EU law on the status of the right to collective action. In commenting on a complaint made by the British Airline Pilot Association (BALPA) the ILO Committee of Experts said with reference to the rulings of the CJEU in Viking Line and Laval: "The Committee observes that when elaborating its position in relation to the permissible restrictions that may be placed upon the right to strike, it has never included the need to assess the proportionality of interests bearing in mind a notion of freedom of establishment or freedom to provide services. (...) The Committee is of the opinion that there is no basis for revising its position in this regard" and that the Committee "considers that the doctrine that is being articulated in these CJEU judgments is likely to have a significant restrictive effect on the exercise of the right to strike in practice in a manner contrary to the Convention". 30

Next out was the Social Rights Committee. The Committee received a complaint from Swedish trade unions on the Swedish implementation of the Posting of Workers Directive after the Laval-ruling. ${ }^{31}$ The complaint alleged that the legislative amendments made in April 2010 (so called "Lex Laval") in the aftermath of the judgment of the CJEU violated Articles 4, 6 and $19 \S 4$ of the Charter. As a general point the committee stated that "neither the current status of social rights in the EU legal order nor the substance of EU legislation and the process by which it is generated would justify a general presumption of conformity of legal acts and rules of the EU with the European Social Charter." 32 As to the right to bargain collectively of Article 6 of the Charter and the Swedish measures, the Committee held by 13 votes to 1 that the act did not adequately recognise the fundamental right to collective action and was therefore not in conformity with article 6 of the Charter.

\footnotetext{
${ }^{30}$ The ILO Committee of Experts (ILO, 2010), Report of the Committee of Experts on the application of Conventions and Recommendations p. 209.

${ }^{31}$ European Committee of Social Rights 85/2012 Swedish Trade Union Confederation (LO) and Swedish Confederation of Professional Employees (TCO) v. Sweden.

${ }^{32}$ European Committee of Social Rights 85/2012 Swedish Trade Union Confederation (LO) and Swedish Confederation of Professional Employees (TCO) v. Sweden para. 74.
} 
The Committee underlined that it is not part of its tasks to "judge the conformity to the Charter of the CJEU's preliminary ruling in the Laval case, but rather to assess whether the legislative amendments adopted by the Swedish Parliament (...) constitute a violation of the Charter." 33 When assessing the statutory framework the Committee noted that in limiting the scope of collective action to regulate the minimum rate of pay or other minimum conditions the legislation imposed substantial limitations on the ability of Swedish trade unions to make use of collective action in establishing binding collective agreements. ${ }^{34}$ It further considered "that national legislation which prevents a priori the exercise of the right to collective action, or permits the exercise of this right only in so far as it is necessary to obtain given minimum working standards would not be in conformity with Article $6 \S 4$ of the Charter, as it would infringe the fundamental right of workers and trade unions to engage in collective action for the protection of economic and social interests of the workers." 35 With address to EU law the Committee further stated that:

"legal rules relating to the exercise of economic freedoms established by State Parties either directly through national law or indirectly through EU law should be interpreted in such a way as to not impose disproportionate restrictions upon the exercise of labour rights (...) Consequently, the facilitation of free crossborder movement of services and the promotion of the freedom of an employer or undertaking to provide services in the territory of other States - which constitute important and valuable economic freedoms within the framework of EU law - cannot be treated, from the point of view of the system of values, principles and fundamental rights embodied in the Charter, as having a greater a priori value than core labour rights, including the right to make use of collective action to demand further and better protection of the economic and social rights and interests of workers. In addition, any restrictions that are imposed on the enjoyment of this right should not prevent trade unions from engaging in collective action to improve the employment conditions, including wage levels, of workers irrespective of their nationality." 36

The implications for the relationship between the Social Charter and EU law as developed by the CJEU is quite clear in the opinion of the Social Committee, even though the statement does not formally address EU law or the jurisprudence of the CJEU.

\section{The Bosphorus hurdle}

Enter the ECtHR and Holship. The ECtHR does not have jurisdiction over the EU and EU law. Under the current legal arrangement, it can only deal with EU law in-

\footnotetext{
${ }^{33}$ European Committee of Social Rights 85/2012 Swedish Trade Union Confederation (LO) and Swedish Confederation of Professional Employees (TCO) v. Sweden para. 107.

${ }^{34}$ European Committee of Social Rights 85/2012 Swedish Trade Union Confederation (LO) and Swedish Confederation of Professional Employees (TCO) v. Sweden para. 112.

${ }^{35}$ European Committee of Social Rights 85/2012 Swedish Trade Union Confederation (LO) and Swedish Confederation of Professional Employees (TCO) v. Sweden para. 120.

${ }^{36}$ European Committee of Social Rights 85/2012 Swedish Trade Union Confederation (LO) and Swedish Confederation of Professional Employees (TCO) v. Sweden para.s 121 and 122.
} 
directly in cases against EU Member states, where it is the application or adherence to EU law which forms the basis for the action which is contested as incompatible with the ECHR. It follows from Article 1 ECHR that "The High Contracting Parties shall secure to everyone within their jurisdiction the rights and freedoms defined in Section I of this Convention". According to the jurisprudence of the ECtHR this obligation prevails also when the state is acting under an obligation undertaken under international law or according to an international treaty. Does this also apply to EU Member States applying EU law? In this case, the ECtHR can exercise an indirect control with the human rights compliance of EU law, through the obligations of the Member States under the ECHR.

In the Bosphorus case Ireland argued that enforcing an EU regulation was not under the "jurisdiction" of Ireland, and that the case therefore fell outside of the scope of the ECHR according to Article $1 .{ }^{37}$ The ECtHR rejected this line of argument and determined that issues are under the jurisdiction of the state even when the Member State is implementing mandatory obligations following from EU law. On the other hand, to the question of whether a measure can be justified as a proportional measure of general interest, the Court referred to the fact that Ireland in this case was acting under an EU obligation, and held that compliance with legal obligations flowing from the Irish State's membership of the European Community must be regarded as a general interest of "considerable weight" under Article 1 of Protocol No. 1 ECHR. ${ }^{38}$ It then went on to state its rule that acting under such obligations could in itself be considered a justification as long as the relevant organisation is considered to protect fundamental rights. The next question was then if and to what extent this could be said to apply to the EU.

Regarding the application of the convention to acts undertaken under an obligation of EU law, the Court stated that "state action taken in compliance with such legal obligations is justified as long as the relevant organisation is considered to protect fundamental rights, as regards both the substantive guarantees offered and the mechanisms controlling their observance, in a manner which can be considered at least equivalent to that for which the Convention provides." 39 Acting in accordance with international obligations therefore under certain conditions justifies the action of the state, namely when the state is acting in accordance with a legal regime that in itself protects fundamental rights.

The ECtHR took a systemic approach when evaluating the level of protection within the EU, and it did not enter an assessment of the protection offered in the individual instance. Also, it did not evaluate the protection of the right in question in substance but limited itself to an evaluation of the institutional set-up and mechanism for the protection and mechanism for control of convention rights. This can be interpreted to mean that there are two ways of rebuttal. Either to show a systemic procedural dysfunction within the EU legal system or to show a failure to provide remedies to an obvious violation of a right protected by the convention. ${ }^{40}$

\footnotetext{
${ }^{37}$ Bosphorus Hava Yollari Turizm ve Ticaret Anonim Siketi v Ireland 2005-VI; 42 EHRR 1

${ }^{38}$ Bosphorus para. 150.

${ }^{39}$ Bosphorus Hava Yollari Turizm Ve Ticaret Anonim Sirketi v. Ireland, Application No. 45036/98, Judgment of the ECtHR (Grand Chamber) of 30 June 2005, (2006) 42 E.H.R.R. 1 para. 155.

${ }^{40}$ Eckes [3], p. 62.
} 
An important issue is whether the test of "equivalent protection" refers to the protection of human rights within the EU as such, or whether it must be undertaken in relation to the specific rights. The decision in Nederlanse Kokkelvisserij seems to indicate that the ECtHR will not open itself for an assessment on a right by right basis. The case here was whether a rejection by the CJEU of a right of a party to comment on the opinion of the Advocate General constituted a violation of article 6 ECHR. Referring to Bosporus the ECtHR stated that "such protection need not be identical to that provided by Article 6 of the Convention; the presumption can be rebutted only if, in the circumstances of a particular case, it is considered that the protection of Convention rights was manifestly deficient." 41

\section{Enter the EEA: first, the unlocking of Bosphorus}

The effect of the Bosphorus doctrine is that the Albany case law has been immunised from a scrutiny by the ECtHR of its compliance with the ECHR. The EEA differs from the EU in many respects, and the question is to what extent these differences are relevant to the application of the Bosphorus doctrine to the EEA. ${ }^{42}$ When the Holship case arose in Norwegian courts and the EFTA Court, this brought an opportunity to take the relation between union rights and free movement to Strasbourg.

It has been argued that the Bosphorus doctrine should be extended to the EEA because the overall protection of fundamental rights here are comparable to the protection offered in the EU. ${ }^{43}$ The ECtHR, however, stated the contrary in an obiter dictum in Konkurrenten. ${ }^{44}$

The EEA agreement does not include any powers to supranational bodies to set out rules. The EFTA states are therefore not acting under an obligation when undertaking to comply with new EU rules. There is an uncertainty to what extent the charter and the broad protection of fundamental rights of the EU are included in the EEA agreement as obligations on the EFTA states under the agreement. This uncertainty is an argument against applying the Bosphorus doctrine and thus depriving individuals or enterprises of access to the ECtHR when EFTA states are applying and enforcing EEA law.

Another aspect is the nature of the protection of the rights by international supervising bodies. Contrary to the EU, the system of co-operation between the EFTA Court and the national courts does not have a binding nature. Formally, national courts are not under an obligation to refer matters to the EFTA Court, and they are not bound by the opinions on EEA law expressed by this court. As pointed out by Barnard, the principles of homogeneity, reciprocity and the duty of loyal cooperation are principles, not mandatory rules, and a more partner-like relationship between the EFTA

\footnotetext{
${ }^{41}$ Cooperatieve Producentenorganisatie Van De Nederlandse Kokkelvisserij U.A. against the Netherlands, Application no. 13645/05, Judgement of the ECtHR 29 January 2009 p. 20.

${ }^{42}$ See Graver [8], pp. 294-308.

${ }^{43}$ See Fredriksen and Johansen [6], p. 734.

${ }^{44}$ ECtHR, decision of 5 November 2019, no. 47341/15, Konkurrenten.no AS v. Norway.
} 
Court and the national courts requested by the EFTA Court requires both courts to listen to each other rather than a subordination of one under the other. ${ }^{45}$

A central feature of the protection of rights within the EU is that reference to the CJEU is mandatory for the courts of last instance of the Member States, and that the opinions expressed by the court are binding for them. Both these features are lacking within the EFTA side of the EEA. The consequence of this is that individuals of the EFTA states have no access to binding judicial review of the decisions taken by the judicial bodies of their states.

In Holship, the ECtHR circumvented most of these issues. It accepted that fundamental rights are part of the EEA, and the fact that the EEA does not include the EU Charter "is not determinative of the question whether the Bosphorus presumption could apply when it comes to the implementation of EEA law" (paragraph 107). The significance of the fact that the EEA does not include supremacy and direct effect, and that the opinions of the EFTA Court are not binding, the court left for a future case to decide. It based its ruling in the Holship case "on the basis that for the purposes of this case the Bosphorus presumption does not apply to EEA law" (paragraph 108). This opened the door for a full review.

\section{The Human Rights approach}

The ECtHR found that there had been no violation of Article 11 ECHR by the decision of the Supreme Court to uphold the ban on the boycott. The reason for this was the large margin of appreciation the ECtHR granted the national authorities in the case, particularly in the light of its specific circumstances. The boycott was directed towards a third party, and it concerned the priority to work for the dock workers as to the workers employed by Holship. Subsequently, the parties had entered into a new collective agreement. Obviously, therefore, there had not been a manifest deficiency in the protection by the Norwegian courts of the rights of the trade union under Article 11 of the case.

The ECtHR could have stopped here. But it went on in some concluding paragraphs to discuss, on a more general basis, the relation between collective rights and free movement. The ECtHR explicitly took issue with the CJEU's statement in Viking that the right to collective action could not be considered inherent to the very exercise of trade unions' rights (paragraph 52). Contrary to this, and closer to reality, the ECtHR stated in Holship "that for a collective action to achieve its aim, it may have to interfere with internal market freedoms such as those at issue in the case before the Supreme Court. [...] [C]reating difficulties for the company in respect of loading and unloading, and the possible negative financial consequences flowing therefrom, would have been an important point of the boycott" (paragraph 117). In other words, it is in the nature of a strike or a boycott that it will impede on the exercise of market freedoms. Not to recognize this is to negate the very right itself. This is exactly what the CJEU does, when it says that it is not inherent in trade union rights to prejudice the "fundamental freedoms". According to the ECtHR it is.

${ }^{45}$ Barnard [2], p. 167. 
In consequence, the mere fact that a collective action restricts a market freedom does not mean that this action must justify itself under the proportionality test under EU law. The ECtHR is explicit about this and states that "the degree to which a collective action risks having economic consequences cannot, therefore, in and of itself be a decisive consideration in the analysis of proportionality under Article 11, paragraph 2 of the Convention" (paragraph 117).

The court continued and took issue with the approach in EU law that freedom of establishment and freedom of organization are rights that must be weighed against each other as part of a consideration of proportionality. Such a "reconciliation" of the rights through a balancing test is not the correct response seen from Strasbourg. Referring to Article 11 of the ECHR, the ECtHR said: "EEA freedom of establishment is not a counterbalancing fundamental right to freedom of association but rather one element, albeit an important one, to be taken into consideration in the assessment of proportionality under Article 11, paragraph 2" (paragraph 118). These are clear words. Restrictions of the rights under the convention must be necessary or proportional, whether they are based on national law or EU law. EU "fundamental freedoms" do, from this perspective, not enjoy the same privileged position on the same level as the human rights of the convention.

\section{Implications}

The result of the ruling, that there had been no violation of the convention by the Norwegian Supreme Court, makes the remarks on the relationship between the Convention and the protection of fundamental rights in the EU, albeit indirectly through dealing with the EEA agreement, remarkable. It is difficult to see this from any other perspective than that the unanimous Fifth Section of the ECtHR wanted to send a message to the EFTA Court and even the CJEU.

The ECtHR's findings in Holship have implications far beyond trade union rights and Article 11 of the ECHR. They go to the core of the CJEU jurisprudence on the protection of human rights. In dealing with other human rights than the right to collective bargaining, the CJEU has not been as clear in subjecting the human right to a clear proportionality test under the free-movement doctrine of mandatory requirements and overriding reasons of public interest. In Schmidberger and Omega, the CJEU held that the exercise of the fundamental rights at issue, the freedoms of expression, of assembly and respect for human dignity, did not fall outside the scope of the provisions of the Treaty. But at the same time, it considered that such exercise must be reconciled with the requirements relating to rights protected under the Treaty and in accordance with the principle of proportionality (see Schmidberger, paragraph 77, and Omega, paragraph 36).

Contrary to the EU, where all "fundamental rights" are on an equal footing (albeit with a preferred position in practice to the market freedoms, at least when confronted with labour rights), the ECtHR maintains a hierarchy of rights, where the rights recognized in the human rights convention are protected by infringements, even by EU fundamental rights.

It will be interesting to see how the other courts will react. The Norwegian Supreme Court must in its practice now subordinate the EEA Agreement to the 
ECHR. This may put Norway in a position where, to fulfill its obligations under the Convention, it will find itself in breach of the EEA Agreement. Under Norwegian law, however, the case seems clear. Most of the Convention rights are recognized in the constitution, and there is no direct effect and supremacy in the EEA Agreement.

In the EU, things are more complicated. The Bosphorus doctrine prevents direct clashes between the CJEU and the ECtHR. The CJEU could take the position that the Holship judgment is only relevant to the EEA, and that it has no significance for EU law. Under the spirit of judicial dialogue, however, the CJEU should nevertheless read the Holship ruling closely. It may signal a more assertive ECtHR towards the EU. It may also indicate that the ECtHR does not regard the protection of labour rights and other rights protected by the ECHR as at least "equivalent" to those for which the Convention provides, with implications for the application of the Bosphorus doctrine.

Thinking ahead, in a setting where climate change is entering the realm of human rights, there is also a potential for stronger conflicts with market freedoms. Strasbourg may not be willing to leave this issue in the hands of Luxembourg. Holship must lead to a recalibration of the protection of rights in Europe, where market freedoms must be exercised within the scope allowed by human rights, and not the other way around.

Funding Note Open access funding provided by University of Oslo (incl Oslo University Hospital).

\section{Declarations}

Conflict of Interest The author, Prof. Hans Petter Graver, acted as a counsel for the Norwegian Confederation of Trade Unions and the Norwegian Transport Workers' Union in the case before the European Court of Human Rights presented in his article.

Open Access This article is licensed under a Creative Commons Attribution 4.0 International License, which permits use, sharing, adaptation, distribution and reproduction in any medium or format, as long as you give appropriate credit to the original author(s) and the source, provide a link to the Creative Commons licence, and indicate if changes were made. The images or other third party material in this article are included in the article's Creative Commons licence, unless indicated otherwise in a credit line to the material. If material is not included in the article's Creative Commons licence and your intended use is not permitted by statutory regulation or exceeds the permitted use, you will need to obtain permission directly from the copyright holder. To view a copy of this licence, visit http://creativecommons.org/licenses/by/ $4.0 \%$.

\section{References}

1. Barnard, C.: Viking and Laval: an introduction. Camb. Yearb. Eur. Legal Stud. 10(1), 463-492 (2007-2008)

2. Barnard, C.: Reciprocity, homogeneity and cooperation in the EFTA Court. In: The EEA and the EFTA Court Decentred Integration. Hart, Oxford (2014)

3. Eckes, C.: Does the European Court of Human Rights provide protection from the European Community? - The case of Bosphorus airways. Eur. Public Law 13(1), 47 (2007)

4. Edström, Ö: The Right to Collective Action as a Fundamental Right in Mia Rönnmar. Labour Law, Fundamental Rights and Social Europe Swedish Studies in European Law, vol. 4. Hart publishing, Oxford (2011)

5. Evju, S.: Fundamental social rights vs. fundamental freedoms. Eur. J. Labour Law 6, 312-323 (2013)

6. Fredriksen, H.H., Johansen, S.Ø.: The EEA Agreement as a Jack-in-the-box in the relationship between the CJEU and the European Court of Human Rights? In: European Papers (EP), pp. 707-743 (2020) 
7. Giubboni, S.: Social Rights and Market Freedom in the European Constitution: A Reappraisal in Kaarlo Tuori and Suvi Sankari, the Many Constitutions of Europe. Ashgate, Surrey (2010)

8. Graver, H.P.: The EEA and the protection of Human Rights. In: Lorenzmeier, S., Folz, H.-P. (eds.) Recht und Realität Festschrift für Christoph Vedder. Nomos, Baden Baden (2017)

9. Höpner, M., Scmidt, S.K.: Can we make the European fundamental freedoms less constraining? A literature review. Camb. Yearb. Eur. Legal Stud. 22, 182-204 (2020)

10. Lasek-Markey, M.: No Turning Back from Social Europe: A New Interpretation of the Refurbished Posted Workers Directive in Hungary and Poland, Industrial Law Journal, 2021, Advanced Access publication on October 22, 2021. Available at: No Turning Back from Social Europe: A New Interpretation of the Refurbished Posted Workers Directive in Hungary and Poland | Industrial Law Journal | Oxford Academic (oup.com)

11. Lasser, M.: Fundamentally flawed: the CJEU's jurisprudence on fundamental rights and fundamental freedoms. Theor. Inq. Law 15, 229-260 (2014)

12. Lenaerts, K.: The Court of Justice of the European Union and the Protection of Fundamental Rights. Pol. Yearb. Int. Law (31) (2011) 79-106. Available at www.ceeol.com

13. Malmberg, J.: Regulating posted work - before and after the Laval quartet. In: Rönnmar, M. (ed.) Labour Law, Fundamental Rights and Social Europe, Swedish Studies in European Law, vol. 4, pp. 77-88. Hart Publishing, Oxford (2011)

14. Stylogiannis, C.: The 'Back and Forth' in the Protection of (Collective) Labor Rights under the ECHR Continues: the Holship Case, Comparative Labor Law and Policy Journal, Dispatch No. 38 Norway. Available at: Microsoft Word - Dispatch No. 38.docx (illinois.edu)

15. Swiatkowski, A.M.: Resocialising Europe through a European right to strike modelled on the Social Charter? In: Nicola Countouris and Mark Freedland, Resocialising Europe in a Time of Crisis. Cambridge University Press, Cambridge (2013)

16. Rebhanh, R.: Rechte des Arbeidslebens (Art. 27 bis 33 GRC). In: Grabenwarter (ed.) Europäischer Grundrechteschutz (EnzEuR Bd.2), pp. 643-644

Publisher's Note Springer Nature remains neutral with regard to jurisdictional claims in published maps and institutional affiliations. 